\title{
BioLink
}

Jurnal Biologi Lingkungan, Industri, Kesehatan

Available online http://ojs.uma.ac.id/index.php/biolink

\section{ETHNOMEDICINE OF BAJO TRIBE COMMUNITY IN BANGKO VILLAGE, MAGINTI DISTRICT, WEST MUNA, SOUTHEAST SULAWESI}

\author{
Fachruddin*, Musthamin Balumbi, \& Dustan \\ Departement Biology, Faculty of Science and Technology, Institut Teknologi dan Kesehatan \\ Avicenna, Indonesia
}

Submited : 21-10-2020; Reviewed :08-11-2020; Accepted : 19-11-2020

${ }^{*}$ Corresponding author: E-mail : fachruddin.ifo@gmail.com

\begin{abstract}
This study aims to reveal the use of marine and coastal plants, and animals as medicine by Bajo Tribe society in Bangko Village, West Muna. The method used was an exploratory survey. Data were collected using in-depth interviews with 20 traditional healers selected by purposive sampling. The data obtained were analyzed descriptively. The result revealed that there were 39 species of plants and 5 species of animals used as medicine. The most widely used plant families were the Arecaceae and Poaceae, 3 species respectively, while animals from the families of Holothuriidae, Onuphidae, Pinnidae, Syngnathidae, and Tridacnidae, 1 species respectively. The most commonly part of plant used was leaves (50\%), while for animal was parts of flesh and whole body were used 40\% respectively. The most commonly used preparation and application were boiling and drinking. In conclusion, Bajo people in Bangko Village with their maritime culture use plants and animals in the marine and coastal environment to overcome various diseases and health problems, in addition using "baca-baca" method.
\end{abstract}

Keywords: Bajo Tribe; Medicinal Plants; Zootheraphy

How to Cite: Fachruddin, Balumbi, M., \& Dustan. (2021). Ethnomedicine of Bajo Tribe Community in Bangko Village, Maginti District, West Muna, Southeast Sulawesi, BioLink: Jurnal Biologi Lingkungan, Industri dan Kesehatan, Vol.7 (2): Hal. 215-226 


\section{INTRODUCTION}

Indonesia is known as a mega diversity country, not only because of its high biodiversity, but also because of its rich cultural diversity. As reported on the web page: www.indonesia.go.id (2020) that Indonesia has 1,340 ethnic groups, one of them is Bajo (Bajau) tribe who are associated with Sulawesi region. Bajo tribe is spread across almost all corners of the country, such as in Riau (known as Duano), North Sulawesi, Central Sulawesi, South Sulawesi, Southeast Sulawesi, East Nusa Tenggara, Maluku and North Maluku (Rahim, et al., 2018). In Southeast Sulawesi, Bajo ethnic settlements can be found in the Wakatobi Islands (Suryanegara et al., 2015), Muna and Buton Tengah (Nur, 2015), and Tiworo Muna Barat Strait (Sampeali, 2011).

Unlike most of the other tribes who inhabit the land area, Bajo tribe is unique because they inhabit the sea and coastal areas and build a unique culture known as maritime culture. The historical records stated that originally the Bajo people lived on a boat called Soppe, with this boat they always moved (sea nomads) to make a living. However, at present, along with the times and the influence of socio-political factors, many Bajo people live in the shallow sea zone or on the coast (Nur, 2015).
The Bajo tribe is a tribe that has a very strong emotional relationship with marine and coastal ecosystems. This tribe has unique local wisdom in the use of natural resources for medicinal purposes. Bajo tribe's traditional medical practice is specifically organized by an institution known as duata institution. This institution was born from the philosophy of life of the Bajo Tribe, namely "living in harmony with nature". Therefore, the traditional healing procession of Bajo tribe cannot be separated from the sea and coastal resources. The Bajo people believe that every type of marine and coastal ecosystem is guarded by supernatural beings in the form of spirits. They believe that the spirits guarding the marine and coastal ecosystems can cause disease. Therefore, the duata will gather when there is a sick man to recognize the spirit of the ecosystem where the disease came (Obie, 2016).

In the traditional medicine practice of Bajo tribe, besides using the method of "baca-baca" (reciting mantras and prayers to God Almighty), it also utilized marine and coastal organisms to overcome the health problems, prevent and cure the diseases, and improve the quality levels. health. The plants and animals have long been an inseparable part of the long history and culture of an ethnic group, including in terms of medicine. However, in practice, 
plants were most widely used given their very large number of species. It is estimated that 9,606 plant species have been used as medicine because they have pharmacological effects (Wiwaha et al., 2012; Aziz et al., 2019).

The use of other non-plant organisms to maintain health and treat various diseases has yet to be revealed. Although in fact there are some animals that can be used for the medicinal purposes. The Bajo tribe community is presumed to have made use of marine and coastal animals in tbe traditional medicine, so it is significant to investigate and reveal how marine and coastal plants and animals are used as medicine by the Bajo people. It is important to further enrich the local cultural treasures and to keep the wealth of traditional knowledge as a national cultural asset from being eroded by the times. This study aimed to explore the local knowledge of the Bajo people in utilizing marine and coastal organisms as ingredients for traditional medicine.

\section{MATERIALS AND METHODS}

The research was conducted in September 2020. The collection of information on medicinal plants and animals was carried out in Bajo Tribe Village in Bangko Village, Maginti District, West Muna Regency. This study has followed the principles of research ethics as presented in the ISE (International Society of Ethnobiology) protocol. The method used in this research was an exploratory survey. Data were collected using interview techniques using structured questionnaires and free interviews to explore more in-depth information about traditional knowledge in using plants and animals as medicine, as well as direct observation in the field (Fanie \& Nuning, 2018). Inventory of the existence (number and identity) of traditional healers (hattra)/informants was carried out with the assistance of a contact person, namely the village head. Informants were determined based on purposive sampling technique (Nisa \& Astana, 2018). Informants were hattras who have expertise in curing health problems and treating diseases by utilizing medicinal plants and animals recognized by the community (Fanie \& Nuning, 2018). The data determined from the interview results include: hattra demographic data, medicinal plant and animal species, parts of plants and animal organs used, preparation method, application method, and names of diseases to be treated. All information was noted and recorded using a sound recorder. Starting from the information from Hattra, then all types of plants and animals with medicinal properties were collected for each sample. The sample collection process 
was accompanied by hattra. Herbarium samples were made in the form of plants, while samples in the form of animals were made into wet preserves. Preservation was carried out for the purpose of imprinting in the Laboratory of the Department of Biology Education, Halu Oleo University. The names of medicinal plants had been verified using the online database, the Plant of the World (POWO).

\section{RESULTS AND DISCUSSION}

\section{Traditional Health Demographics}

Based on the results of interviews with 20 hattras in Bangko Village, it was known that most of the hattres were male (80\%), aged between 55-64 years (55\%), have graduated from elementary school/ equivalent (55\%), and have main jobs as fishermen $(80 \%)$. The demographics of the hattra are shown in Table 1 below.

Table 1. Demographics of Hattra

\begin{tabular}{lc}
\hline \multicolumn{1}{c}{ Hattra Demographics } & Amount (N = 20) \\
\hline Gender & 16 \\
Male & 4 \\
Women & 4 \\
\hline Age (years) & 11 \\
$45-54$ & 3 \\
$55-64$ & 2 \\
$65-74$ & 3 \\
$75-84$ & 6 \\
\hline Education & 11 \\
No school & \\
Not completed in primary school & 16 \\
Graduated from elementary school / equivalent & 1 \\
\hline The main job & 3 \\
Fisherman & 3 \\
Carpenter & \\
Private & \\
\hline
\end{tabular}

\section{Plants and Animals with Medicinal} Benefits in Bajo Tribe in Bangko Village

The results revealed that there were 39 types of plants and 5 types of animals that were used as medicine by the Bajo tribe's hattra in Bangko Village (Table 2). Plants and animals that are used as medicine have various properties. Some of these types of plants and animals have the same use in terms of the treatment of a particular species diseases or health problems, for example Holothuria scabra, Diopatra sp., and Tridacna sp. equally useful as vitality-enhancing drugs. 
Table 2. Plants and animals with medicinal properties in Bangko Village

\begin{tabular}{|c|c|c|c|c|c|}
\hline Family & $\begin{array}{c}\text { Species Name / } \\
\text { Local Name }\end{array}$ & Parts Used & $\begin{array}{c}\text { Method of } \\
\text { Preparation } \\
\end{array}$ & $\begin{array}{c}\text { Method of } \\
\text { Application }\end{array}$ & Uses \\
\hline \multicolumn{6}{|l|}{ Plant } \\
\hline Anacardiaceae & $\begin{array}{l}\text { Anacardium } \\
\text { occidentale/ } \\
\text { Jajambo }\end{array}$ & Trunk & Boiled & Drink it & Ulcer \\
\hline Annonaceae & $\begin{array}{l}\text { Annona } \\
\text { muricata/Sirisak }\end{array}$ & Leaf & Boiled & Drink it & Diuretic \\
\hline Araliaceae & $\begin{array}{l}\text { Polyscias } \\
\text { scutellaria/ } \\
\text { Mangko }\end{array}$ & Leaf & Smoothed & Smeared & Facial skin care \\
\hline \multirow[t]{3}{*}{ Arecaceae } & $\begin{array}{l}\text { Cocos nucifera/ } \\
\text { Saloka }\end{array}$ & Fruit & $\begin{array}{l}\text { Shredded; } \\
\text { Baked / fried }\end{array}$ & $\begin{array}{l}\text { Drunk; Smeared; } \\
\text { Sticked; Dropped }\end{array}$ & $\begin{array}{l}\text { Make labor } \\
\text { easier; } \\
\text { Postpartum care; } \\
\text { Wound; Itchy; } \\
\text { Scabies; } \\
\text { Poisoning; } \\
\text { Kidney disorders; } \\
\text { Cough }\end{array}$ \\
\hline & $\begin{array}{l}\text { Nypa fruticans/ } \\
\text { Tutuho }\end{array}$ & Leaf & Pounded & Sticked & $\begin{array}{l}\text { Swelling from the } \\
\text { bite of a } \\
\text { centipede }\end{array}$ \\
\hline & $\begin{array}{l}\text { Areca catechu/ } \\
\text { Pinah }\end{array}$ & Fruit & Pounded & Smeared & Wound \\
\hline Asteraceae & $\begin{array}{l}\text { Eupatorium } \\
\text { odoratum/ Sheep }\end{array}$ & Leaf & $\begin{array}{l}\text { Smoothed; } \\
\text { Pounded }\end{array}$ & Drunk; Sticked & $\begin{array}{l}\text { Internal disease; } \\
\text { Diarrhea; Wound }\end{array}$ \\
\hline Bromeliaceae & $\begin{array}{l}\text { Ananas comosus/ } \\
\text { Look }\end{array}$ & Leaf & Shredded & Smeared & Leprosy \\
\hline Caricaceae & $\begin{array}{l}\text { Carica papaya/ } \\
\text { Katela }\end{array}$ & Leaf & Boiled & Drink it & Tumor \\
\hline Convolvulaceae & $\begin{array}{l}\text { Ipomoea pes- } \\
\text { caprae/ Kakatah }\end{array}$ & Leaf & Boiled & Drink it & Diabetes \\
\hline \multirow[t]{2}{*}{ Cucurbitaceae } & $\begin{array}{l}\text { Cucumis sativus/ } \\
\text { Boyo }\end{array}$ & Fruit & & Be eaten & Hypertension \\
\hline & $\begin{array}{l}\text { Momordica } \\
\text { charantia/ Paria }\end{array}$ & Leaf & Boiled & Drink it & Cough \\
\hline Euphorbiaceae & $\begin{array}{l}\text { Phyllanthus } \\
\text { niruri/ Gutters }\end{array}$ & Others & Boiled & Drink it & $\begin{array}{l}\text { Liver; stomach; } \\
\text { tumor }\end{array}$ \\
\hline \multirow[t]{2}{*}{ Fabaceae } & $\begin{array}{l}\text { Arachis } \\
\text { hypogaea/ } \\
\text { Canggoreng }\end{array}$ & Seed & Fried / baked & Be eaten & $\begin{array}{l}\text { Breast milk } \\
\text { production } \\
\text { accelerator }\end{array}$ \\
\hline & $\begin{array}{l}\text { Derris elliptica/ } \\
\text { Tuba }\end{array}$ & Exudate & - & Dropped & $\begin{array}{l}\text { Prevent infection } \\
\text { in puncture } \\
\text { wounds }\end{array}$ \\
\hline \multirow[t]{2}{*}{ Lamiaceae } & $\begin{array}{l}\text { Pogostemon } \\
\text { cablin/ Dandila }\end{array}$ & Leaf & Smoothed & Smeared & Facial skin care \\
\hline & $\begin{array}{l}\text { Orthosiphon } \\
\text { aristatus/ Cat } \\
\text { whiskers }\end{array}$ & Leaf & Boiled & Drink it & $\begin{array}{l}\text { Liver; gastric } \\
\text { disorders, tumors }\end{array}$ \\
\hline \multirow[t]{2}{*}{ Liliaceae } & $\begin{array}{l}\text { Allium Cepa/ } \\
\text { Under mireh }\end{array}$ & Bulbs & $\begin{array}{l}\text { Shredded; } \\
\text { Smoothed }\end{array}$ & Smeared; Sticked & Fever; Tooth ache \\
\hline & $\begin{array}{l}\text { Allium sativum/ } \\
\text { Under the puteh }\end{array}$ & Bulbs & Fried / baked & Be eaten & Cough \\
\hline Loranthaceae & $\begin{array}{l}\text { Macrosolen sp./ } \\
\text { Balaang }\end{array}$ & Trunk & $\begin{array}{l}\text { Smoothed; } \\
\text { Boiled }\end{array}$ & Smeared; Drink it & $\begin{array}{l}\text { Chronic cough } \\
\text { Internal disease }\end{array}$ \\
\hline Lythraceae & $\begin{array}{l}\text { Sonneratia alba/ } \\
\text { Beropa }\end{array}$ & Fruit & Shredded & Sticked & $\begin{array}{l}\text { Boils, accelerate } \\
\text { wound closure }\end{array}$ \\
\hline
\end{tabular}


Fachruddin, Balumbi, M., \& Dustan. Ethnomedicine of Bajo Tribe Community in Bangko Village, Maginti District, West Muna, Southeast Sulawesi

\begin{tabular}{|c|c|c|c|c|c|}
\hline Malvaceae & $\begin{array}{l}\text { Kleinhovia } \\
\text { hospita/ } \\
\text { Lantoghe } \\
\end{array}$ & Leaf & Boiled & Drink it & $\begin{array}{l}\text { Liver, Stomach, } \\
\text { Tumors }\end{array}$ \\
\hline Moringaceae & $\begin{array}{l}\text { Moringa oleifera/ } \\
\text { Moringa }\end{array}$ & Leaf & Smoothed & Dropped & Eye inflammation \\
\hline Muntingiaceae & $\begin{array}{l}\text { Muntingia } \\
\text { calabura/ } \\
\text { Kerseni } \\
\end{array}$ & Leaf & Boiled & Drink it & Hypertension \\
\hline Myrtaceae & $\begin{array}{l}\text { Psidium guajava/ } \\
\text { Jambo Malacca }\end{array}$ & Leaf & - & Be eaten & Cough \\
\hline Oxalidaceae & $\begin{array}{l}\text { Averrhoa bilimbi/ } \\
\text { Balumbi }\end{array}$ & Leaf & Boiled & Drink it & Hypercholesterol \\
\hline Piperaceae & Piper betle/ Leko & Leaf & Smoothed & Dropped & $\begin{array}{l}\text { Visual } \\
\text { disturbances }\end{array}$ \\
\hline \multirow[t]{3}{*}{ Poaceae } & Zea mays/Good & Seed & Fried / baked & Drink it & $\begin{array}{l}\text { Lowering fever, } \\
\text { cough }\end{array}$ \\
\hline & $\begin{array}{l}\text { Cylindrical } \\
\text { imperata/ Rome }\end{array}$ & Root & Boiled & Drink it & $\begin{array}{l}\text { Lowering fever, } \\
\text { Improve mood, } \\
\text { Antidepressants }\end{array}$ \\
\hline & $\begin{array}{l}\text { Cymbopogon } \\
\text { citratus/Sere }\end{array}$ & Trunk & Boiled & Drink it & Hypertension \\
\hline Rhizophoraceae & $\begin{array}{l}\text { Rhizophora } \\
\text { apiculata/ } \\
\text { Bangko } \\
\end{array}$ & Trunk & Smoothed & Sticked & $\begin{array}{l}\text { Wounds, Itching, } \\
\text { Boils, Smallpox }\end{array}$ \\
\hline \multirow[t]{2}{*}{ Rubiaceae } & Coffea sp./ Coffee & Seed & - & Sticked & Wound \\
\hline & $\begin{array}{l}\text { Uncaria gambier/ } \\
\text { Gambir }\end{array}$ & Leaf & Smoothed & Drink it & Chapter bleeding \\
\hline \multirow[t]{2}{*}{ Rutaceae } & $\begin{array}{l}\text { Citrus } \\
\text { aurantifolia/ } \\
\text { Lime lime }\end{array}$ & Fruit; Leaf & $\begin{array}{l}\text { Pounded; } \\
\text { Kneaded }\end{array}$ & Dropped; Inhaled & $\begin{array}{l}\text { Prevent infection; } \\
\text { Speed up wound } \\
\text { closure; Motion } \\
\text { sickness }\end{array}$ \\
\hline & $\begin{array}{l}\text { Aegle marmelos/ } \\
\text { Blade }\end{array}$ & Fruit & Shredded & Sticked & Heals burns \\
\hline Solanaceae & $\begin{array}{l}\text { Nicotiana } \\
\text { tabacum/ Tabako }\end{array}$ & Leaf & Chopped & Smeared & $\begin{array}{l}\text { Itching stings by } \\
\text { jellyfish }\end{array}$ \\
\hline Verbenaceae & $\begin{array}{l}\text { Lantana camara/ } \\
\text { Kambea kakuni }\end{array}$ & Leaf & Smoothed & Sticked & Wounds, boils \\
\hline \multirow[t]{2}{*}{ Zingiberaceae } & $\begin{array}{l}\text { Curcuma longa/ } \\
\text { Kunye }\end{array}$ & Rhizome & Smoothed & Smeared & $\begin{array}{l}\text { Facial skin care; } \\
\text { Itchy }\end{array}$ \\
\hline & $\begin{array}{l}\text { Costus speciosus/ } \\
\text { Cane lance }\end{array}$ & Trunk & Shredded & Drink it & $\begin{array}{l}\text { Kidney disorders, } \\
\text { heartburn, Liver }\end{array}$ \\
\hline \multicolumn{6}{|l|}{ Animal } \\
\hline Holothuriidae & $\begin{array}{l}\text { Holothuria } \\
\text { scabra/ Bale } \\
\text { popote }\end{array}$ & Meat & Boiled & Be eaten & Vitality \\
\hline Onuphidae & $\begin{array}{l}\text { Diopatra sp./ } \\
\text { Bantunang }\end{array}$ & Whole body & Boiled & Drink it & Vitality \\
\hline Pinnidae & $\begin{array}{l}\text { Pinna sp./ Bole } \\
\text { tenabur }\end{array}$ & Shell & Burnt, shaved & Smeared & $\begin{array}{l}\text { Itchy mouth; } \\
\text { Tongue yeast } \\
\text { infection (oral } \\
\text { thrush) }\end{array}$ \\
\hline Syngnathidae & $\begin{array}{l}\text { Hippocampus } \\
\text { sp./ Tandundo }\end{array}$ & Whole body & Dried, boiled & Drink it & $\begin{array}{l}\text { Bone pain; } \\
\text { Internal disease }\end{array}$ \\
\hline Tridacnidae & $\begin{array}{l}\text { Tridacna sp./ } \\
\text { Kima }\end{array}$ & Meat & Boiled & Be eaten & Vitality \\
\hline
\end{tabular}


However, there are also several types of plants and animals that have medicinal properties for more than one type of disease, such as Cocos nucifera (saloka) which was used to facilitate childbirth, postpartum care, deep tearing, itching, scabies, poisoning, kidney disorders, and cough. Things that were not much different can also be found in Bajo tribe in Torosiaje Village, Gorontalo Province who also used several types of plants for the same types of disease and one type of plant to overcome more than one type of disease or health problem that appears (Utina \& Katili, 2016).

The Family of Plants and Animals Used as Medicine by Bajo Tribe in Bangko Village

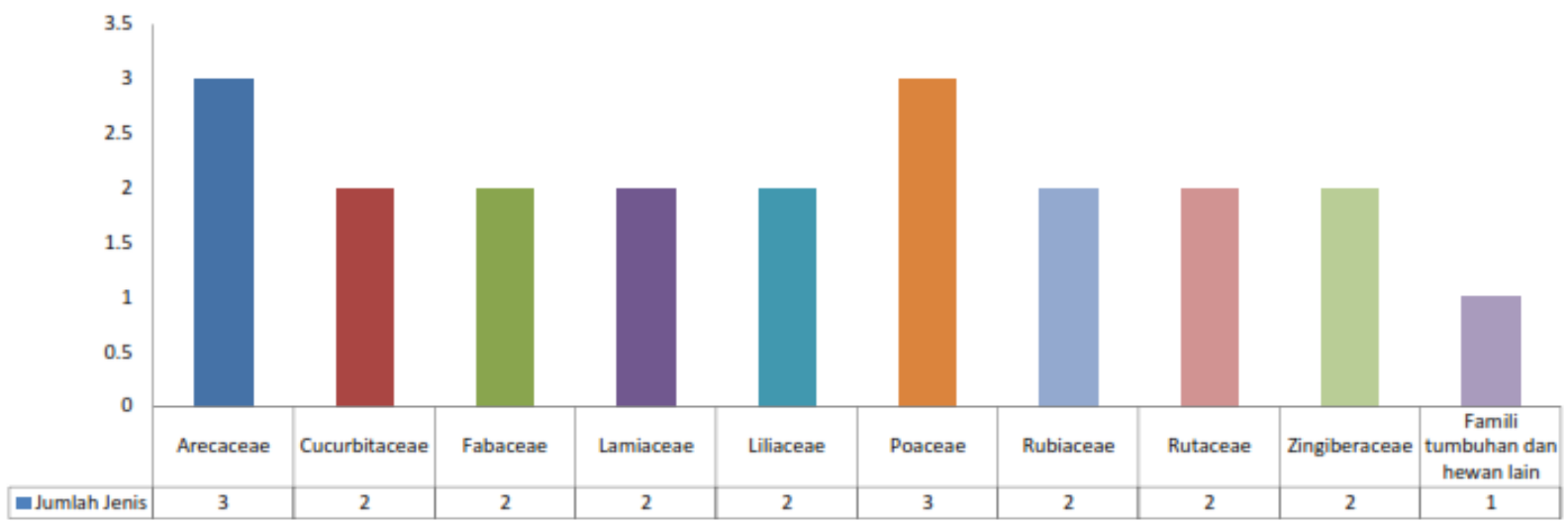

Figure 1. Family of Medicinal Plants and Animals

The Bajo tribe community used a lot of plants from the Arecaceae family because this plant family grew well around their places of residence, namely in coastal
Taxonomically, the organisms used as medicinal substances by Bajo tribe came from 27 plant families and 5 animal families. The most common plant families were Arecaceae and Poaceae, each of them consisted of 3 types of plants, namely Cocos nucifera (saloka), Nypa fruticans (tutuho), and Areca catechu (pinah) for the Arecaceae and Zea mays (jago), Imperata cylindrica (roma), and Cymbopogon citratus (sere) for the Poaceae family. The second most abundant families were Cucurbitaceae, Fabaceae, Lamiaceae, Liliaceae, Rubiacecae, and Zingiberaceae which each of them consisted of 2 types of plants, while the other 18 families and the 5 animal families each of them only consisted of 1 type (Figure 1).

Village

3 
to have a chemical constitution that was useful for the normal functioning of the human body. Cocos nucifera (saloka) fruit, for example, is reported to have medicinal properties as antibacterial, antifungal, antidermatophytic, hepatoprotective, immunostimulant (Debmandal \& Mandal, 2011) anti diabetic, cardio protective effect, and antiatherosclerosis (Venugopal et al., 2017), while Areca catechu (pinah) has the potential to overcome parasitic diseases, digestive dysfunction, and anti depressants (Peng et al., 2015). Meanwhile, Nypa fruticans (tutuho) is known to contain phenol and flavonoid compounds which are good as natural antioxidants (Prasad et al., 2013; Lubis et al., 2017).

\section{Percentage of Plant and Animal Body} Parts Used as Medicine by Bajo Tribe in

\section{Bangko Village}

The Bajo people in Bangko Village generally used the leaves of plants (50\%) as medicine, followed by the fruits (15\%) and the stems (12\%). Meanwhile, the use of animals as medicine came from the flesh (40\%), the whole body (40\%), and the shell (20\%) (Figure 2).

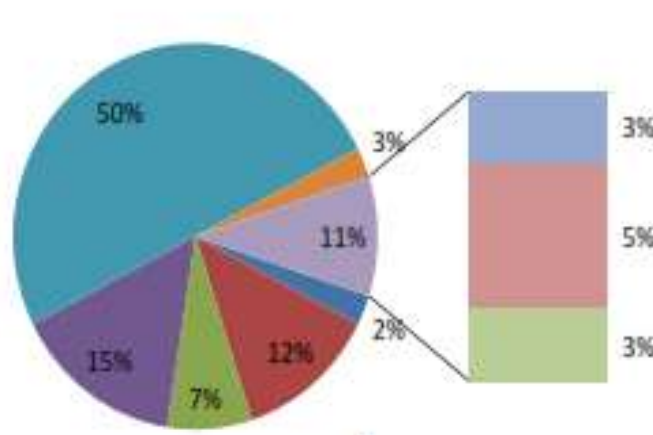

A

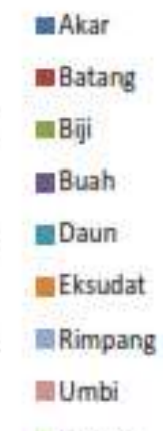

ivinna Laing

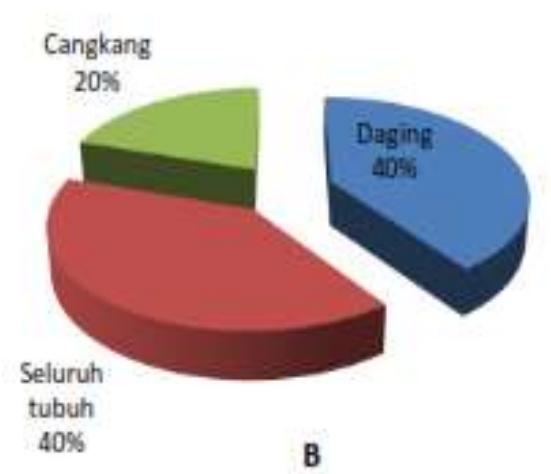

B

Figure 2. Percentage of Body Parts (A) Plants and (B) Animals which are Used as Medicine

The higher percentage of leaf organ use compared to other plant organs in Bajo tribe can actually be found in other tribes as reported in many ethnomedicine studies. There were several reasons that make leaf as a plant organ that was most often used as medicine compared to other organs, including easy access, adequate supply and unlimited time, processing is relatively simple, physiologically contains many organic substances, and is ecologically more environmentally. According to (Fanie \& Nuning, 2018), leaf organ is obtained, cleaned and processed easily. In addition, leaf as an organ where photosynthate accumulation is considered to be more effective in treating diseases because they contain many organic 
substances that have pharmacological bothered by the unpleasant smell and taste effects (Roudatuljannah \& Azizah, 2019). of animals (Akhsa et al., 2015).

On the other hand, the leaf was considered more profitable ecologically because their extraction did not cause damage to the plant body which can threaten its survival. Leaves have rapid regeneration when harvested or picked (Namukobe et al., 2011), so they can be used continuously and sustainably.

In animals, the part that was used as a medicinal ingredient, namely most parts of the flesh and the whole body. Animals that were used their whole bodies as medicine had characteristics of small body sizes, so that it was easier to use all of their bodies than having to remove or dispose of other body parts. The use of the flesh part was mainly due to the ease of processing, as well as the relatively pleasant application of the drug because the user was not

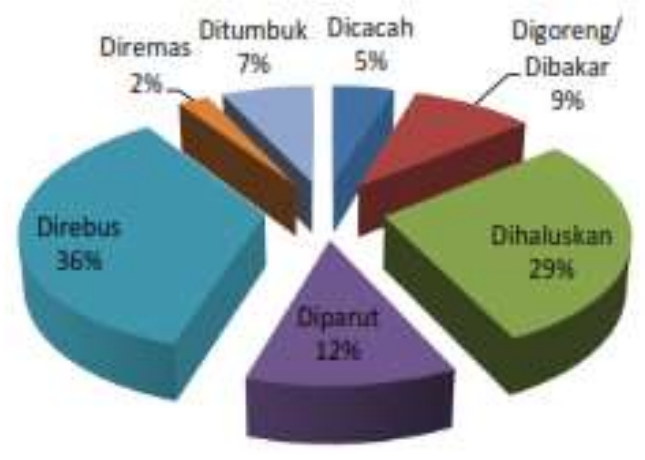

A

\section{Percentage of Plant and Animal} Preparation Methods Used as Medicine by Bajo Tribe in Bangko Village

The processing of medicinal substances was basically aimed at increasing the efficacy and or reducing the effect of its toxicity (Heinrich \& Jager, 2015). The method of preparation of medicinal plants and animals by Bajo tribe in Bangko Village consisted of several methods, such as chopping, mashing, grating, boiling, and others. However, the most widely applied method of both plant and animal preparation was by boiling $36 \%$ and $60 \%$, respectively. Other methods also widely used were mashing (29\%) and grating (12\%) (Figure 3).

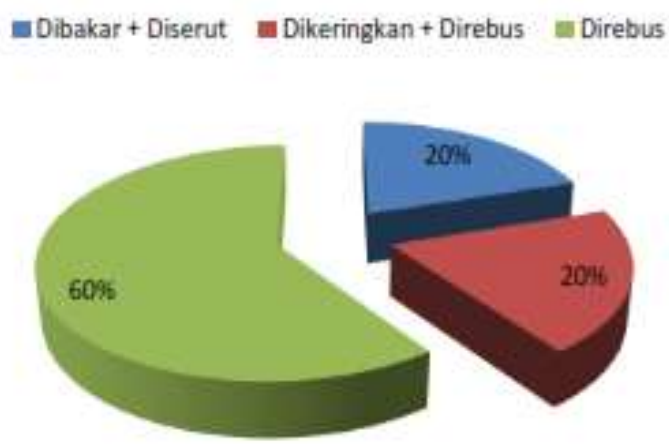

B

Figure 3. Percentage of (A) Plants and (B) Animals Preparation Methods which is Used as Medicine 
The choice of preparation method was closely related to the plant or animal material and the type of disease being treated. Using the roots and stems, for example, the most common preparation method was boiling. Likewise with internal applications and for internal diseases, usually the method of preparation of drug samples was by boiling (Wildayati et al., 2016). The way of boiling was considered more effective because of the compounds contained in many medicinal ingredients which are extracted in heated water, it was also more efficient because the boiling method can be done repeatedly.

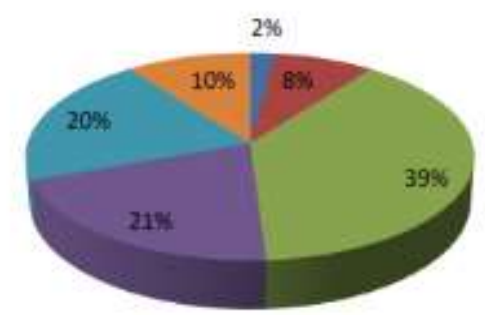

A
Percentage of Plant and Animal Application Methods Used as Medicine by Bajo Tribe in Bangko Village

The Bajo people in Bangko Village practiced six ways of applying preparated medicinal substances, namely inhaling, eating, drinking, smearing, sticking, and dropping. For plants, the most widely used way of application was by drinking (39\%), then smearing and sticking by $21 \%$ and $20 \%$, respectively. Whereas for animals, the application method was drinking and eating (40\%) and smearing (20\%) (Figure 4).

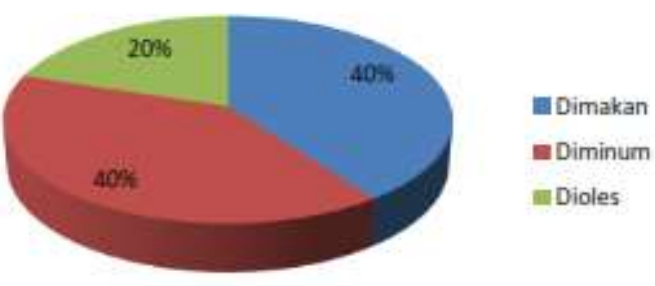

B

Figure 4. Percentage of Application Method (A) Plants and (B) Animals which is Used as Medicine

The choice of application method regarded as the method of preparation and the type of disease to be treated. The application by drinking was directly proportional to the high percentage of the boiling method in the preparation of medicinal substances. In addition, the way it was taken was generally used to treat types of internal diseases, such as hypertension, indigestion, kidney, liver problems, and so on.

\section{CONCLUSION}

The Bajo tribe community in Bangko Muna Barat Village with their maritime culture used plants and animals found in the marine and coastal environment to overcome various diseases and health problems, in addition to using the "bacabaca" method. There were 39 types of plants and 5 types of animals that were identified as medicinal ingredients, with plant leaves and meat and animal organs 
being the most widely used. The processing and application of medicinal substances derived from plants and animals was mostly done by boiling and drinking.

\section{ACKNOWLEDGEMENT}

Thanks are conveyed to the Directorate of Research and Development, Ministry of Research and Technology/National Research and Innovation Agency for funding this research through the National Research Grant for Beginner Lecturer Research Scheme for the 2020 Fiscal Year.

\section{REFERENCES}

Akhsa, M. Pitopang, R. \& Anam, S. (2015). Studi Etnobiologi Bahan Obat-Obatan pada Masyarakat Suku Taa Wana di Desa Mire Kecamatan Ulubongka Kabupaten Tojo Una Una Sulawesi Tengah. Biocelebes. 9(1): 58-72.

Aziz, I. R., Raharjeng, A. R. P., \& Nasution, J. (2019, March). Ethnobotany of traditional wedding: a comparison of plants used by Bugis, Palembang, Sundanese and Karo ethnic in Indonesia. In Journal of Physics: Conference Series (Vol. 1175, No. 1, p. 012005). IOP Publishing.

DebMandal, M. \& Mandal, S. (2011). Coconut (Cocos nucifera L.: Arecaceae): In Health Promotion and Disease Prevention. Asian Pacific Journal of Tropical Medicine. 4(3): 241-247.

Fanie, I.M. \& Nuning, R. (2018). Studi Etnofarmakologi Tumbuhan Obat yang Digunakan oleh Penyehat Tradisional untuk Mengatasi Diare di Sulawesi Selatan. Jurnal Tumbuhan Obat Indonesia. 11(2): 17-32.

Heinrich, M. \& Jager, A.K. (2015). Ethnopharmacology. UK: John Wiley \& Sons Ltd.

Lubis, R., Nasution, J., \& Kardhinata, EH. (2017). Kajian Etnobotani Tumbuhan Mangrove
Oleh Masyarakat Kampung Nipah Dusun Iii Desa Sei Nagalawan Kecamatan Perbaungan Kabupaten Serdang Bedagai Sumatera Utara. Jurnal Biosains 3(1), 9-13.

Namukobe, J. Kasenen, J.M. Kiremire, B.T. Byamukama, R. Kamatenesi-Mugisha, M. Krief, S. Dumontet, V. \& Kabasa, J.D. (2011). Traditional Plant Used for Medicinal Purposes by Local Communities Around The Northern Sector of Kibale National Park, Uganda. Journal of Etnhnopharmacology. 136: 236-245.

Nisa, U. \& Astana, P.R.W. (2018). Studi Etnofarmakologi Tumbuhan Obat untuk Mengobati Gangguan Batu Saluran Kemih di Sumatera Indonesia. Buletin Penelitian Kesehatan. 46(4): 275-286.

Nur, S.S. (2015). Pola Penguasaan dan Pemanfaatan Wilayah Perairan Pesisir Secara TurunTemurun oleh Suku Bajo. Prosiding Seminar Nasional Multidisiplin Ilmu \& Call for Papers UNISBANK (SENDI_U): Kajian Multidisiplin Ilmu untuk Mewujudkan Poros Maritim dalam Pembangunan Ekonomi Berbasis Kesejahteraan Rakyat. ISBN: 978-979-364981-8.

Obie, M. (2016). Perubahan Sosial pada Komunitas Suku Bajo di Pesisir Teluk Tomini. Al-Tahrir. 16(1): 153-174.

Peng, W. Liu, Y.J. Wu, N. Sun, T. He, X.Y. Gao, Y.X. \& Wu, C.J. (2015). Areca catechu L. (Arecaceae) : A Review of Its Traditional Uses, Botany, Phytochemistry, Pharmacology, and Toxicology. Journal of Ethnopharmacology. 164: 340-356.

Prasad, N. Yao, B. Kong, K.W. Khoo, K.E. Sun, J. Azlan, A. Ismail, A. \& Romli, Z. (2013). Phytochemicals and Antioxidant Capacity from Nypa fruticans Wurmb. Fruit. eCAM. 2013. Article ID 154606, 9 pages.

Rahim, M. Basri, A. \& Fauzi, H. (2018). Typology of Bajo Tribe Settlement in North Maluku. IOP Conf. Ser.: Earth Envirin. Sci. 213012028.

Roudatuljannah, Y. \& Azizah, N. (2019). Studi Etnofarmasi Tumbuhan yang Berkhasiat Obat di Kampung Adat Cireundeu. Herbapharma. 1(2): 44-51.

Sampeali, Y. (2011). Perilaku Komunikasi Suku Bajo dalam Berinteraksi dengan Komunitas Daratan di Desa Terapung Kecamatan 
Fachruddin, Balumbi, M., \& Dustan. Ethnomedicine of Bajo Tribe Community in Bangko Village, Maginti District, West Muna, Southeast Sulawesi

Mawasangka Kabupaten Buton. Jurnal Komunikasi KAREBA. 1(3): 230-235.

Suryanegara, E. Suprajaka, \& Nahib, I. (2015). Perubahan Sosial pada Kehidupan Suku Bajo: Studi Kasus di Kepulauan Wakatobi, Sulawesi Tenggara. Majalah Globe. 17(1): 067078.

Utina, R. \& Katili, A.S. (2016). Pemanfaatan Ekosistem Pesisir dalam Eksplorasi Pengetahuan Lokal Tumbuhan Obat Berbasis Komunitas Etnis Bajo Torosiaje Serumpun. JURNAL PENGABDIAN: Sinergitas Pengabdian untuk Publik. 2(7): 439-443.
Venugopal, A. Rinu, K.A. Joseph, D. (2017). Cocos nucifera: It's Pharmacological Activities. World J Pharm Sci. 5(8): 195-200.

Wildayati T., Lovadi I., dan Linda R. (2016). Etnomedisin Penyakit Dalam pada Suku Dayak Tabun di Desa Sungai Areh Kecamatan Ketungau Tengah Kabupaten Sintang. Protobiont. Vol. 4 (3): 1-7.

Wiwaha, G. Jasaputra, S.N.B.D.K. Rohmawaty, E. Yumivita, K.D.V. \& Muhtar, E. (2012). Ethnoharmacology Observation of Medicinal Plant/ Traditional Medicinal Ingredient for Dyslipidemia Treatment in West Java Local Wisdom. Jurnal Medika Planta. 2(1): 62-68. 